\title{
Terveyden lukutaito - ajankohtainen mutta vähän tutkittu kansalaistaito
}

\author{
Johanna Eronen
}

Maailman terveysjärjestö WHO:n määritelmän mukaan terveyden lukutaidolla tarkoitetaan "niitä kognitiivisia ja sosiaalisia taitoja, jotka määrittävät yksilöiden motivaation ja kyvyn hankkia, ymmärtää ja käyttää tietoa tavoilla, jotka edistävät ja tukevat hyvää terveyttä" (Nutbeam 1998). WHO:n mukaan terveyden lukutaito on sekä yksilön että yhteisöjen resurssi, joka voi mahdollistaa yksilölle paremmat mahdollisuudet pitää huolta terveydestään ja yhteisöille ja yhteiskunnalle keinon kaventaa terveyseroja ja terveyden eriarvoisuutta (Kickbush ym. 2013, 7-8). Terveyden lukutaidon käsite otettiin käyttöön 1970-luvulla, ja aluksi siihen liittyvää tutkimusta tehtiin pääasiassa Yhdysvalloissa ja Kanadassa, mutta varsinkin viimeisten viidentoista vuoden aikana terveyden lukutaidon tutkimus ja sen huomioiminen terveyden edistämisen toimenpiteissä ja terveyspolitiikoissa on lisääntynyt myös $\mathrm{Eu}-$ roopassa (Sorensen ym. 2012).

Useimmiten terveyden lukutaitoa tarkastellaan joko kliinisestä tai kansanterveysnäkökulmasta. Kliininen näkökulma on ollut käytetympi lähestymistapa Yhdysvalloissa, jossa terveyden lukutaitoa ja erityisesti siinä olevia puutteita on tarkasteltu pääasiassa terveyden riskitekijöinä (Pleasant \& Kuruvilla 2008), ja sitä on mitattu taitona ymmärtää kirjoitettuja ohjeita, kuten esimerkiksi lääkepakkauksen ohjetekstiä oikeasta annostelusta (Parker ym. 1995). Kansanterveysnäkökulmasta terveyden lukutaidon sitä vastoin ajatellaan olevan hyvän terveyden resurssi ja kertovan yksilön kompetenssista ja koetusta pystyvyydestä: kuinka helposti yksilö uskoo löytävänsä, ymmärtävänsä ja osaavansa käyttää hyödykseen erilaista ja eri lähteistä saatavaa terveyteen liittyvää tietoa (Sorensen ym. 2012). Hyvä terveyden lukutaito on tällöin terveyden voimavara, joka kertoo siitä, että yksilölle terveyteen liittyvän tiedon löytäminen, ymmärtäminen ja hyödyntäminen on helppoa. Tärkeä osa terveyden lukutaitoa on myös kyky navigoida terveyspalvelujärjestelmässä: mistä ja miten saa tarvitsemansa terveyspalvelut silloin, kun se on ajankohtaista. Tämä on ollut yleisempi lähestymistapa eurooppalaisissa tutkimuksissa, ja siitä näkökulmasta sitä tarkastellaan myös tässä kirjoituksessa.

Iäkkäillä ihmisillä terveyden lukutaito korreloi terveyteen ja terveyskäyttäytymiseen liittyvien tekijöiden kanssa. Henkilöt, joilla on parempi terveyden lukutaito, ovat fyysisesti aktiivisempia, he syövät terveellisemmin ja heillä on parempi itsearvioitu terveys (Aaby ym. 2017) sekä parempi terveyteen liittyvä elämänlaatu ja matalampi kakkostyypin diabeteksen riski (Tiller ym. 2015). Heikko terveyden lukutaito on puolestaan yhteydessä esimerkiksi suurempaan pitkäaikaissairauksien lukumäärään (Sorensen ym. 2015), ja se ennustaa runsaampaa terveyspalveluiden käyttöä (Berens ym. 2016). Heikon terveyden lukutaidon vaikutukset ulottuvat myös yksilöä kauemmas. Esimerkiksi iäkkäiden henkilöiden omaishoitajien terveyden lukutaito on yhteydessä koettuihin 
vaikeuksiin yhteydenpidossa terveydenhuollon toimijoiden kanssa ja hoitojärjestelyjen tekemisessä. Siten se vaikuttaa myös hoidettavan tilanteeseen (Fields ym. 2018).

Terveyden lukutaito on yhteydessä sosioekonomisiin tekijöihin. Esimerkiksi taloudellisen niukkuuden on todettu olevan yhteydessä matalampaan (Sorensen ym. 2015; Vogt ym. 2018) ja korkeamman koulutuksen parempaan terveyden lukutaitoon (Tiller ym. 2015). Iän merkityksestä eri tutkimukset ovat esittäneet ristiriitaisia tuloksia. Yhdysvalloissa korkea ikä on luettu yhdeksi matalan terveyden lukutaidon riskitekijäksi (Paasche-Orlow ym. 2005), mutta viimeaikaisissa eri-ikäistä väestöä kartoittaneissa eurooppalaisissa tutkimuksissa korkeamman iän on todettu olevan yhteydessä sekä heikompaan (Sorensen ym. 2015; Vogt ym. 2018) että parempaan terveyden lukutaitoon (Tiller ym. 2015; Svendsen ym. 2020) nuorempiin väestöryhmiin verrattuna. Suomalaisten ikäihmisten terveyden lukutaitoa kartoitettiin vuosina 2017-2018 osana Jyväskylän yliopistossa toteutettua Aktiivisuuden, terveyden ja toimintakyvyn yhteys hyvinvointiin vanhuudessa (AGNES) -tutkimusta (Rantanen ym. 2018). AGNES-tutkimuksessa terveyden lukutaitoa mitattiin European Health Literacy Surveyn mittarilla, ja ensimmäisten tulosten mukaan 75-vuotiaista jyväskyläläisistä 12 prosentilla terveyden lukutaito oli erinomainen, 51 prosentilla hyvä, 32 prosentilla kohtalainen ja 5 prosentilla heikko (Eronen ym. 2019). Kahdeksassa EU-maassa (Itävalta, Bulgaria, Saksa, Kreikka, Irlanti, Hollanti, Puola ja Espanja) tehdyn väestöpohjaisen tutkimuksen mukaan yli 76-vuotiaiden terveyden lukutaidon taso vaihtelee eri maiden välillä huomattavasti: Hollannissa 29 prosentilla terveyden lukutaito oli kohtalainen tai heikko, kun taas Bulgariassa vastaava osuus oli 75 prosenttia (Sorensen ym. 2015). Kun kaikkien kahdeksan maan osallistujia tarkasteltiin yhdessä, kohtalaisen ja heikon terveyden lukutaidon osuus oli 61 prosenttia yli 76-vuotiailla ja 58 prosenttia 66-75-vuotialla (Sorensen ym. 2015).
Terveyden lukutaidon merkitys korostui keväällä 2020, kun koronavirus ja sen aiheuttama tauti covid-19 järjestelivät maailman uudelleen (Abel \& McQueen 2020). Samalla kun virus eteni väestössä aiheuttaen sairastumisia ja kuolemaa, lukuisissa eri tiedonvälityskanavissa ja sosiaalisessa mediassa eteni virusta ja sairautta koskeva tieto. Nopeasti kävi ilmi, että tiedon ohella levisi myös väärä ja vääristelty tieto. Infodemia - oikean ja väärän tiedon nopea leviäminen (Rothkopf 2003) - oli omiaan hankaloittamaan entisestään pandemiatilannetta ja sen hallintaa (Ratzan ym. 2020). Oikean ja luotettavan tiedon tunnistaminen silloin, kun on kiire löytää vastauksia, on haastavaa niin tavallisille kansalaisille, tutkijoille kuin viranomaisillekin. Esimerkiksi muutaman korkeatasoisen tieteellisen julkaisun toimittajat hyväksyivät kevään aikana julkaistavaksi tekstejä, jotka myöhemmässä tarkastelussa vedettiin pois niiden osoittauduttua perustuvan puutteelliseen tietoon (Pihlava 2020). Suomessa sosiaali- ja terveysministeriön ohjeistus kunnille ja asumispalveluyksiköille hoivakotien vierailukielloista tulkittiin sitovaksi ja velvoittavaksi, mutta eduskunnan apulaisoikeusasiamies Maija Sakslin huomautti ratkaisussaan ohjeistuksen olleen virheellinen ja vierailujen kieltämisen ja rajoittamisen olleen lainvastaista (EOAK 3232/ 2020). Tutkimustiedon ja ohjeistusten ristiriitaisuus ja epäselvyydet voivat heikentää kansalaisten luottamusta tieteeseen (Ratzan ym. 2020). Tosin Sitran huhti-toukokuussa 2020 teettämän kyselytutkimuksen mukaan suomalaisista 61 prosenttia uskoo tieteen ja asiantuntijuuden merkityksen lisääntyvän sen jälkeen, kun koronapandemian pahimmat terveysongelmat on ohitettu (Vahti 2020).

Reuters-instituutin tekemän Digital News Reportin mukaan suomalaisten luottamus uutisiin ja uutismediaan on kansainvälisesti verrattuna melko korkea (Reunanen 2019), mutta median uskotaan kuitenkin levittävän myös virheellistä tietoa (Sivonen \& Saarinen 2018). Iäkkäiden ihmisten terveyden lukutaidon näkökulmasta erityisesti mediassa olevan tiedon 
luotettavuuden arviointi ja ymmärtäminen vaikuttaa olevan haastavaa. Kun tarkastelimme AGNES-tutkimuksessa käyttämämme terveyden lukutaidon mittarin kysymyksiin tulleita vastauksia yksitellen, havaitsimme vastaajien raportoineen eniten vaikeuksia nimenomaan niissä kysymyksissä, joissa tarkasteltiin mediassa olevan tiedon hyödyntämistä ja sen luotettavuuden arviointia (Eronen ym. 2019). Esimerkiksi kysymykseen "kuinka helppoa sinun on arvioida, onko median väittämä tieto terveysriskeistä luotettavaa" 48 prosenttia vastasi "melko vaikeaa" ja 3 prosenttia "hyvin vaikeaa", ja kysymykseen "kuinka helppoa sinun on päättää median välittämän tiedon perusteella kuinka voit suojautua sairaudelta" 48 prosenttia vastasi "melko vaikeaa" ja 6 prosenttia "hyvin vaikeaa". Esimerkiksi kysymykseen "kuinka helppoa sinun on käyttää lääkäriltä saamaasi tietoa sairauteesi liittyvässä päätöksenteossa" puolestaan vain 8 prosenttia vastasi "melko vaikeaa" ja 1 prosentti "hyvin vaikeaa". Terveyden lukutaidon ohella merkittävä taito nykyään onkin medialukutaito (Ratzan ym. 2020), jonka merkitys Suomessa on tunnistettu ja sisällytetty politiikkadokumentteihin useilla eri hallinnonaloilla (Palsa \& Salomaa 2020). Yksi syy näiden kahden lukutaidon merkityksen korostumiseen on yhteiskunnan digitalisoituminen ja monien palveluiden siirtyminen kasvokkain tapahtuvista sähköisiksi.

Sähköisiksi terveyspalveluiksi (eHealth services) luetaan muun muassa sähköiset asiointipalvelut (Suomessa esim. Omakanta, Hyvis), terveysaiheiset sivustot (esim. Duodecimin Terveyskirjasto) ja terveyden omaseurantaan tarkoitetut laitteet (kellot ja rannekkeet). Niillä on todettu olevan iäkkäille käyttäjilleen lukuisia hyötyjä, kuten tiedon ja ymmärryksen lisääntyminen, viestinnän paraneminen ja päätöksenteon helpottuminen, mutta myös negatiivisia seurauksia, kuten ahdistuksen ja stressin lisääntyminen sekä huoli yksityisyyteen kajoamisesta (Hirvonen ym. 2020). Digitaalisten terveyspalveluiden saavutettavuus ei myöskään ole yhdenvertaista: esimerkiksi matalammassa sosio- ekonomisessa asemassa olevilla on todennäköisemmin puutteita paitsi laitteista ja taidoista myös mielenkiinnosta digitaalisuutta kohtaan (Tilles-Tirkkonen ym. 2018; Hänninen ym. 2020). Pirhonen ja kumppanit (2020) tuovat esiin digitalisaation kahdet kasvot: samaan aikaan kun monet iäkkäät ihmiset käyttävät digilaitteita ja -palveluita luontevasti ja lisääntyvissä määrin, jäävät toiset näiden palveluiden ulottumattomiin. Todennäköisimpiä digipalveluiden käyttäjiä ovat ne ikäihmiset, joilla on mahdollisuus saada läheisiltä apua ja opastusta laitteiden ja palveluiden käyttöön (Hänninen ym. 2020). Laitteiden ja toimivien yhteyksien lisäksi terveystietoa verkosta hakeva tarvitsee myös terveyden lukutaitoa digitaalisessa kontekstissa (eHealth literacy). Luotettavan tiedon löytäminen ja tunnistaminen edellyttää muun muassa taitoa käyttää laitteita ja ohjelmia, kykyä arvioida tiedonlähteiden luotettavuutta sekä taitoa kyseenalaistaa löytyvää tietoa ja suhtautua siihen kriittisesti (Griebel ym. 2018). Eriarvoisuus on tullut esiin myös useissa tutkimuksissa, jotka ovat käsitelleet terveyden lukutaitoa digitaalisessa kontekstissa. Iäkkäitä ihmisiä sähköisten terveyspalveluiden käyttäjinä ja terveystiedon etsijinä jakavat koulutustaso, ikä ja käytettävissä olevat resurssit. Parempaan terveyden lukutaitoon digitaalisessa kontekstissa on yhteydessä nuorempi ikä, korkeampi koulutus ja käytettävissä olevien laitteiden lukumäärä (Tennant ym. 2015; Arcury ym. 2020).

Terveyden lukutaidon ajankohtaisuus liittyy myös yhteiskunnassa meneillään oleviin muutoksiin. Pääministeri Sanna Marinin hallituksen ohjelmaan $(2019,151)$ on kirjattu keinoiksi sosiaali- ja terveyspalveluiden saatavuuden parantamiseksi digitalisoinnin hyödyntäminen moniammatillisissa sosiaali- ja terveyskeskuksissa sekä digitaalisten ja mobiileiden palveluratkaisujen käyttö. Terveyden lukutaidon näkökulmasta palveluiden kehittämisessä sekä myös sote-uudistuksen suunnittelussa ja myöhemmin toimeenpanossa olisi erittäin tärkeää huolehtia siitä, että kehitettävä järjestelmä on kansalaisten suuntaan selkeä ja ymmärrettävä ra- 
kenteeltaan. Nykyiseen hallitusohjelmaan kirjattujen tulevien sotekeskusten asiakaskeskeisyydessä ja asiakaslähtöisyydessä (Pääministeri Sanna Marinin... 2019, 151) sekä sosiaaliturvan selkeyttämisessä (Pääministeri Sanna Marinin... 2019, 157) olisi tärkeää huomioida väestössä esiintyvät erot terveyden lukutaidossa ja varmistaa esimerkiksi palveluketjujen ja hoitopolkujen ymmärrettävyys ja loogisuus kaikenikäisten asiakkaiden näkökulmasta. Lisäksi digitalisaation kehitystä ja sen vaikutuksia tulee seurata muutenkin kuin vain teknologianäkökulmasta. Väestöliiton tutkijat Anna Rotkirch ja Kristiina Tammisalo huomauttavat, että digitalisaation vaikutuksista arkeen ja hyvinvointiin ei ole vielä saatavilla riittävän yksityiskohtaista tietoa ja että Suomessa ei ole tahoa, joka seuraisi digitalisaation sosiaalista kestävyyttä laaja-alaisesti (Rotkirch \& Tammisalo 2020, 1-3). Suunnittelussa ja toimeenpanossa on huomioitava myös ikäihmisten moninaisuus. Esimerkiksi maahanmuuttajilla on muuta väestöä todennäköisemmin matalampi terveyden lukutaito ja huonompi terveystiedon ja -palveluiden saavutettavuus (Kickbush ym. 2013, 19-21).

Toistaiseksi iäkkäiden ihmisten terveyden lukutaitoa on Suomessa tutkittu informaatiotutkimuksen alalla (esim. Eriksson-Backa ym. 2012), mutta terveystieteissä terveyden luku-

\section{Kirjallisuus}

Aaby A, Friis K, Christensen B, Rowlands G, Terkildsen Maindal H. Health literacy is associated with health behavior and self-reported health: a large population-based study in individuals with cardiovascular disease. Eur J Prev Cardiol 2017;24(17):1880-8. https://doi.org/10.1177/2047487317729538

Abel T, McQueen D. Critical health literacy and the COVID-19 crisis. Health Promot Int 2020;35(6):1612-3. https://doi.org/10.1093/heapro/daaa040

Arcury T, Sandberg J, Melius K, Quandt S, Leng $\mathrm{X}$, Latulipe $\mathrm{C}$ ym. Older adult Internet use and taidon tutkimus Suomessa on keskittynyt kouluikäisiin lapsiin ja nuoriin (esim. Paakkari ym. 2019). Aiheen tarkempi tutkiminen terveystieteissä ja erityisesti gerontologian alalla tuo uutta tietoa terveyden lukutaidon merkityksestä nimenomaan iäkkäiden ihmisten terveyden ja toimintakyvyn edistämiseen sekä sairauksien ja toiminnanvajausten ennaltaehkäisyyn. Tutkimuksella voidaan myös tuottaa terveyspalveluissa työskenteleville ammattilaisille tietoa terveyden lukutaidon huomioimisesta asiakasja potilastyössä. Ulkomaisissa tutkimuksissa on todettu, että terveyspalveluissa työskentelevien ammattilaisten voi olla vaikea arvioida asiakkaidensa terveyden lukutaidon tasoa, mikä puolestaan voi johtaa siihen, että ohjeet ja neuvot annetaan siten, että asiakas ymmärtää ne puutteellisesti tai jopa väärin (van der Heide ym. 2018). Tutkimustietoa tarvitaan myös siitä, miten terveyden lukutaito selittää ja ennustaa perusterveydenhuollon ja erikoissairaanhoidon palveluiden sekä iäkkäille ihmisille suunnattujen sosiaali- ja asumispalveluiden käyttöä.

\section{Yhteydenotto:}

Johanna Eronen, $\mathrm{Tt} T$, yliopistonlehtori

Gerontologian tutkimuskeskus,

liikuntatieteellinen tiedekunta

Jyväskylän yliopisto

johanna.eronen@jyu.fi

eHealth literacy.J Appl Gerontol 2020;39(2):14150. https://doi.org/10.1177/0733464818807468

Berens EM, Vogt D, Messer M, Hurrelmann K, Schaeffer D. Health literacy among different age groups in Germany: results of a cross-sectional survey. BMC Public Health 2016;16:e1151. https://doi.org/10.1186/s12889-016-3810-6

EOAK 3232/2020. Vanhuksiin kohdistuvat rajoitukset koronaepidemian aikana. Eduskunnan apulaisoikeusasiamiehen ratkaisu 18.6.2020.

Eriksson-Backa K, Ek S, Niemelä R, Huotari ML. Health information literacy in everyday life: a study of Finns aged 65-79 years. Health Infor- 
matics J 2012;18(2):83-94. https://doi.org/10.1177/1460458212445797

Eronen J, Paakkari L, Portegijs E, Saajanaho M, Rantanen T. Assessment of health literacy among older Finns. Aging Clin Exp Res 2019;31(4):54956. https://doi.org/10.1007/s40520-018-1104-9

Fields B, Rodakowski J, James E, Beach S. Caregiver health literacy predicting healthcare communication and system navigation difficulty. Fam Syst Health 2018;36(4): 482-92. https://doi.org/10.1037/fsh0000368

Griebel L, Enwald H, Gilstad H, Pohl A, Moreland J, Sedlmayr M. eHealth literacy research - quo vadis?Inform Health Soc Care 2018;43(4):42742. https://doi.org/10.1080/17538157.2017.1364247

Hirvonen N, Enwald H, Känsäkoski H, Eriksson-Backa K, Nguyen H, Huhta AM, Huvila I. Older adults views on eHealth services: a systematic review of scientific journal articles. Int J Med Inform 2020;135:e104031.

https://doi.org/10.1016/j.ijmedinf.2019.104031 doi: 10.1016/j.ijmedinf.2019.104031

Hänninen R, Taipale S, Luostari R. Exploring heterogeneous ICT-use among older adults: the warm experts' perspective. New Media Soc 2020. https://doi.org/10.1177\%2F1461444820917353

Kickbush I, Pelikan J, Apfel F, Tsouros A. Health literacy: the solid facts. World Health Organization: Regional Office for Europe, 2013.

Nutbeam D. Health promotion glossary. Health Promot Int 1998;13(4):349-64.

Paakkari L, Torppa M, Paakkari O, Välimaa R, Ojala K, Tynjälä J. Does health literacy explain the link between structural stratifiers and adolescent health? Eur J Public Health 2019;29(5):919-24. https://doi.org/10.1093/eurpub/ckz011

Paasche-Orlow M, Parker R, Gazmarian J, NielsenBohlman L, Rudd R. The prevalence of limited health literacy. J Gen Intern Med 2005;20(2):175-84.

https://dx.doi.org/10.1111\%2Fj.15251497.2005.40245.x

Palsa L, Salomaa S. Media literacy as a cross-sectoral phenomenon: media education in Finnish ministerial-level policies. Cent Eur J Commun 2020;13(2):162-82. https://doi.org/10.19195/1899-5101.13.2(26).2

Parker R, Baker D, Williams M, Nurss J. The test of functional health literacy in adults: a new instrument for measuring patients' literacy skills. J Gen Intern Med 1995;10(10):537-41.

https://doi.org/10.1007/bf02640361

Pihlava M. Tiedejulkaisut ovat peruneet ainakin 15 korona-artikkelia. Suomen Lääkärilehti 2020;75(24-33):1492.

Pirhonen J, Lolich L, Tuominen K, Jolanki O, Timonen $V$. "These devices have not been made for older people's needs" - older adults' perceptions of digital technologies in Finland and Ireland. Technol Soc 2020;62:e101287.

https://doi.org//10.1016/j.techsoc.2020.101287

Pleasant A, Kuruvilla S. A tale of two health literacies: public health and clinical approaches to health literacy. Health Promot Int 2008;23(2):152-9. https://doi.org/10.1093/heapro/dan001

Pääministeri Sanna Marinin hallituksen ohjelma 10.12.2019. Osallistava ja osaava Suomi - sosiaalisesti, taloudellisesti ja ekologisesti kestävä yhteiskunta. Valtioneuvoston julkaisuja 2019:31.

Rantanen T, Saajanaho M, Karavirta L, Siltanen S, Rantakokko M, Viljanen A ym. Active aging resilience and external support as modifiers of the disablement outcome: AGNES cohort study protocol. BMC Public Health 2018;18:e565. https://doi.org/10.1186/s12889-018-5487-5

Ratzan S, Sommariva S, Rauh L. Enhancing global health communication during a crisis: lessons from the COVID-19 pandemic. Public Health Res Pract 2020;30(2):e3022010. https://doi.org/10.17061/phrp3022010

Reunanen E. Uutismedia verkossa 2019. Reutersinstituutin Digital News Report Suomen maaraportti. Media-alan tutkimussäätiö, Journalismin, viestinnän ja median tutkimuskeskus, 2019. Internet: https://www.mediaalantutkimussaatio. fi/wp-content/uploads/Reuters_Digital_News_ Report_Suomi_2019.pdf (viitattu 8.7.2020).

Rothkopf D. When the buzz bites back. The Washington Post, 11.5.2003. Internet: https:// www.washingtonpost.com/archive/opinions/2003/05/11/when-the-buzz-bites-back/ bc8cd84f-cab6-4648-bf58-0277261af6cd/ (viitattu 8.7.2020).

Rotkirch A, Tammisalo K. Poliittiset toimenpiteet digitaalisen hyvinvoinnin edistämiseksi. Policy brief 18/2020. Näkökulmia ajankohtaisiin yhteiskunnallisiin kysymyksiin ja poliittisen päätöksenteon tueksi. Valtion selvitys- ja tutkimustoiminta, 2020. 
Sivonen J, Saarinen A. (2018). Puolueiden kannattajien luottamus mediaan. Yhteiskuntapolitiikka 2018;83(3):287-93.

Sorensen K, Van den Broucke S, Fullam J, Doyle G, Pelikan J, Slonska $Z$ ym. Health literacy and public health: a systematic review and integration of definitions and models. BMC Public Health 2012;12:e80.

https://doi.org/10.1186/1471-2458-12-80

Sorensen K, Pelikan J, Röthlin F, Ganahl K, Slonska $Z$, Doyle G ym. Health literacy in Europe: comparative results of the European Health Literacy Survey (HLS-EU). European Journal of Public Health 2015;25(6):1053-58.

https://doi.org/10.1093/eurpub/ckv043

Svendsen MT, Bak CK, Sorensen K, Pelikan J, Riddersholm SJ, Skals RK ym. Associations of health literacy with socioeconomic position, health risk behavior, and health status: a large national population-based survey among Danish adults. BMC Public Health 2020;20:e565 https://doi.org/10.1186/s12889-020-08498-8

Tennant B, Stellefson M, Dodd V, Chaney B, Chaney $\mathrm{D}$, Paige S, Alber J. eHealth literacy and Web 2.0 health information seeking behaviors among baby boomers and older adults. J Med Internet Res. 2015;17(3):e70. https://doi.org/10.2196/jmir.3992

Tiller D, Herzog B, Kluttig A, Haerting J. Health literacy in an urban elderly East-German popu- lation - results form the population-based

CARLA study. BMC Public Health 2015;15:e883.

https://doi.org/10.1186/s12889-015-2210-7

Tilles-Tirkkonen T, Lappi J, Karhunen L, Harjumaa M, Absetz P, Pihlajamäki J. Sosioekonomisesti heikommassa asemassa olevien kiinnostus ja mahdollisuudet digitaalisten terveyspalveluiden käyttöön. Yhteiskuntapolitiikka 2018;83(3):31723.

Vahti J. Tuore kysely: Yli puolet suomalaisista uskoo tieteen ja asiantuntijuuden merkityksen kasvavan koronakriisin jälkeen. Uutinen Sitran Kansanvallan peruskorjaus -projektin kyselytutkimuksesta, julkaistu 8.7.2020. Internet: https://www.sitra. fi/uutiset/tuore-kysely-yli-puolet-suomalaisista-uskoo-tieteen-ja-asiantuntijuuden-merkityksen-kasvavan-koronakriisin-jalkeen/ (viitattu 8.7.2020).

van der Heide I, Poureslami I, Mitic W, Shum J, Rootman I, FitzGerald J. Health literacy in chronic disease management: a matter of interaction. J Clin Epidemiol 2018;102:134-8. https://doi.org/10.1016/j.jclinepi.2018.05.010

Vogt D, Schaeffer D, Messer M, Berens EM, Hurrelmann K. Health literacy in old age: results of a German cross-sectional study. Health Promot Int 2018;33(5):739-47. https://doi.org/10.1093/heapro/dax012 